Niger Agric. J. 32 (2001): 1-11

\title{
EFFECTS OF SEED DRESSING FUNGICIDES ON BLAST DISEASE OF RICE UNDER DIFFERENT WATER REGIMES
}

\author{
IMOLEHIN, E. D and E. A. MAJI \\ Rice Research Programme \\ National Cereals Research Institute (NCRI), Badeggi
}

(Accepted May, 2001)

\section{ABSTRACT}

Investigations on the efficacy of different seed dressing fungicides; Apron plus (Metalaxy), Carboxin, Furathiocab); Benlate (Benomyl) and Fongorene (Pyroquilon) on the rice blast disease (Pyricularia oryzae) were carried out in the laboratory and under two water regimes in the field. All the fungicides tested significantly $(\mathrm{P}=\leq 0.05)$ improved seed germination under laboratory conditions. None of the fungicides showed any signtficant $(\mathrm{P}=\leq 0.05)$ differences on shoot growth, while only Fongorene showed significant $(P=\leq 0.05)$ differences on root length of the test varieties. Fongorene also significantly reduced the incidence and severity of blast in FARO 29 under hydromorphic than the flooded water regime. The chemicals showed significant effect on tiller number and height of rice, except under flooded condition in Faro 11. Benlate - and Fongorene - treated plants had significantly higher yields than the untreated controls and plants treated with Apron plus. 


\section{INTRODUCTION}

Blast, caused by Pyricularia oryzae Cav. is a highly destructive and the most prevalent disease of rice in Nigeria (Awoderu, 1970 and Imolehin, 1987) and in most other rice producing areas of the world (Ou, 1985).

The extent of damage caused by the disease as measured by incidence and severity depends on factors like the physiological race of the pathogen; rice varieties employed, cultural practices and the prevailing environmental factors $1 \mathrm{Ou}$; 1985; Reddy and Satyanarayana, 1988, Singh and Bhatt, 1986) Infection of rice plant by blast is not limited to any particular, stage of development of the rice plant (Imolehin, 1983). Leaf blast is more predominant at the vegetative stage, while the neck blast. which is capable of infecting the base of the panicle is more devastating at the ripening and reproductive stages. As a result of variation in the susceptibility of rice plants to the disease, a number of attempts have been made in the past in selecting resistant varieties as a control measure for the disease. However, the rapid formation of new physiological races of $P$. oryzae (Awoderu, 1970; 1990 and Nagaraju, 1988) makes resistance in cultivars to break down after some times.

Ou (1995) reported that neck blast could be controlled with kitazin when applied at 2 litres per hectare at heading and flowering. He mentioned that under high blast pressure, application of this fungicide resulted in marked yield increase.

Efficacy of NF-48 (hyphenate) on both leaf and panicle blast depends on the disease pressure and precipitation pattem (Signh and Batt 1986). Report by Nakazawa (1985), indicated that Fongorene-50 (Pyroquilon) seed treatment at the rate of $4 \mathrm{~g} / \mathrm{kg}$ seeds reduced leaf blast incidence by as much as $21 \%$. However, Benlate and Hinosan (ediferphos) were effective on blast only when applied foliarly at $250 \mathrm{~g}$ i.e. $\mathrm{ha}^{-1}$ and $400 \mathrm{ml}$ i.e.. ha ${ }^{-1}$ respectively (OU, 1994).

Inadequate and inappropriate use of fertilizer by most farmers makes the rice plants prone to the blast disease. The rice blast, a disease aggravàted by drought often becomes more devastating when 
unsuitable water regimes are of controlling the disease espeemployed. (Awoderu, 1970). cially if there is an epidemic Considering the vinulence of (Awoderu 1974). However, P. oryzae and its ability to pro- awareness on the use of such duce new races, the use of fun- fungicides in rice production gicides remains the most feasi- systems in Nigeria is still low, ble and most effective means but simple improved seed

\section{Table 1: Standard Evaluation System Scale for Rice (IRRI}

Scale

Characteristics Symptoms

0 . Small brown specks of pin-point size or larger brown specks without sporulating center

1 Small roundish to slightly elongated, necrotic gray spots, about $1-2 \mathrm{~mm}$ in diameter, with a distinct brown margin. Lesions are mostly found on the lower leaves.

2 Lesion types is the same as in scale 2, but a significant number of leisons are on the upper leaves.

3 Typical susceptible blast lesions*, $3 \mathrm{~mm}$ or longer infection less than $2 \%$ of the leaf area.

4 Typical blast leisons infecting 2-10\% of the leaf area.

5 Typical blast leisons infecting 11-25\% of the leaf area.

6 Typical blast leisons infecting 26-50\% of the leaf area.

7 Typical blast leisons infecting 51-75\% of the leaf area and many leaves dead.

8 More than $75 \%$ leaf area affected

$9 \quad$ No lesions

Entries. with consistent rating between 4 and 6 with overall average not higher than 5.5 may have a good level of quantitative resistance. 
dressing techniques can be adopted by the peasant farmer. This will eliminate the cost of fungicide application and make production more profitable.

This experiment was designed to assess the efficacy of three systemic seed dressing fungicides in the control of rice blast disease under two different water regimes.

\section{MATERIALS AND METHODS}

\section{Effect of Seed Treatment with} Fungicides

The rice test varieties used were FAROS 11 and 29 known to be susceptible to blast disease. They were obtained from the CIBA-GEIGY Limited, Lagos. Application of the fungicides was by the slurry method. $50 \mathrm{gm}$ of metalaxyl (Apron plus) was dissolved in $100 \mathrm{ml}$ of water each in two bowls to form slurry and $1 \mathrm{~kg}$ each of FAROS 11 and 29 rice seeds were soaked separately. The contents were shaken thoroughly for 5 minutes (Imolehin, 1987). Similarly, $1 \mathrm{~kg}$ of rice seeds of varieties FAROs 11 and 29 were separately treated with $50 \mathrm{~g}$ of Fongorene and $50 \mathrm{~g}$ Benomyl. Seeds for control experiment were soaked in tap water without the chemicals for the same number of minutes. Seeds from each treatment were placed or moist filter papers in sterilized petridishes at the rate of 50 seeds per dish.

Each treatment was replicated 3 times, petri-dishes were arranged on the laboratory table at $27^{\circ} \mathrm{C}$ in a randomised complete block design. The number of seeds that germinated were counted five days after. seeding. Shoot and root lengths were also measured. One thousand seeds from each treatment were planted on nursery beds of $1.2 \mathrm{~m} \times 5 \mathrm{~m}$, replicated four times,' using randomized complete block design. A germination counts were carried out ten days after planting.

An equivalent of $80 \mathrm{~kg} \mathrm{~N} / \mathrm{ha}$ was applied as a basal dosage to the nursery bed before the seeds were planted. Grass straw was used to cover the bed for 7 days to reduce soil moisture evaporation, enhance germination and protect seed against damage by birds and rodents. 
Effect of Seed Treatment and Water Level on Rice Blast.

Twenty seven days after sowing, rice seedlings were scored for disease severity by assessing the percentage leaf area/ hill/plot affected by blast disease lesions. While disease incidences were determined by assessing the $\%$ distribution of lesions/hill/plot. These were read on a scale (0-9) Standard Evaluation System (SES) (Table 1) designed by International Rice Research Institute
(IRRI) (1990). The following day seedlings were transplanted at a spacing of $20 \mathrm{~cm} x$ $20 \mathrm{~cm}$ into two different fields under hydromorphic and flooded conditions. The rice plants were àgain rated for blast at tillering and booting stage means of the two values were used.

\section{RESULTS AND DISCUSSION}

\section{Effect of Seed Treatment on}

Table 2: Effects of Seed Dressing Fungicides on the Percentage Germination Shoot and Root lengths of Two Rice Varie-

Treatment Shoot length $(\mathrm{cm})$ Root length $(\mathrm{cm})$ Germination $\mathbf{S}$

Faro 29 Faro 11 Faro 29 Faro 11 Faro 29 F a ro 11
A p r o n $1.5 \mathrm{c}$
$1.6 \mathrm{c}$
$3.6 \mathrm{a}$
$3.3 \mathrm{a}$
78.0a
$76.7 \mathrm{a}$
plus

Fongorene 1.2c

$1.4 \mathrm{c}$

$2.3 b$

$2.4 b$

$81.3 b \quad 80.0 b$

Benomyl $1.6 \mathrm{c}$

$1.6 \mathrm{c}$

$3.4 a$

$3.2 \mathrm{a}$

$78.7 \mathrm{a}$

$76.0 \mathrm{a}$

Control

$1.7 \mathrm{c}$

$1.7 \mathrm{c}$

$3.7 \mathrm{a}$

$3.6 a$

$64.7 \mathrm{c}$

$64.7 \mathrm{c}$

Figure with similar letter in each column are not significantly different at (P $\leq 0.05)$ using Duncan Multiple Range Test (DMRT). 


\section{Germination}

Table 2 shows the results of seed treatment with fungicides on germination, shoot and root lengths. It showed that the percentage seed germination was significantly $(\mathbf{P} \leq 0.05)$ different between treatments and generally higher with FARO 29. In both varieties, fongorene had the highest percentage germination of $81.3 \%$ in FARO 29 and $80 \%$ in FARO 11 and are significant at $P \leq 0.05$. All the tested fungicides significantly $(P \leq 0.05)$ influenced seed germination over the untreated control and their interactions were significant. None of the chemicals tested was observed to depress germination in the seed of the rice varieties evaluated.

The result of shoot and root lengths (Table 2) showed that only fongorene had significant $(P<0.05)$ depressed the root lengths of germinating seed of the two varieties used in this trial. There was no significant interaction between the chemicals and the varieties.

In FARO 29 the roots and shoots of fongorene-treated rice seeds were $2.3 \mathrm{~cm}$ and 1.2 $\mathrm{cm}$ long respectively and in FARO 11. the values were 2.4 $\mathrm{cm}$ and $1.3 \mathrm{~cm}$ respectively. In control experiments figures of $3.7 \mathrm{~cm}$ for root lengths and 1.7 $\mathrm{cm}$ for shoot length in FARO 29 were obtained, while FARO 11 had values of 3.6 $\mathrm{cm}$ for shoot and $1.6 \mathrm{~cm}$ for root lengths.

The fungicides at the rates used in these studies might have caused the reduction in root and shoot length of rice seedlings. This may be due in part to the quantity of the fungicides used and the interference of the fungicides with the meristematic activities of the root and shoot. However, these reductions will have no effect on yield.

The germination percentage of the seeds of rice varieties (FARO 11 and FARO 29) dressed using these fungicides; Benomyl, Apron plus and fongorene in the laboratory was significantly $(P \leq 0.05)$ enhanced. This finding supports an earlier study by Kannaiyan and Radharkrishanan (1992). The improvement of seed germination by the application of these same fungicides might have resulted from the suppression of seed-borne pathogens by these fungicides. Imolehin (1983) recorded on rice a host of such seed-borne pathogens and reported that 
they reduced on rice a host of such seed-borne pathogens and reported that they reduced the germination of infected seeds. To improve seed germination, the use of such promising fungicides by our farmers should be encouraged.
Effect of Seed Treatment on Rice Blast Development

Table 3 shows effect of seed treatment with fungicides on the incidence of rice blast disease.

The incidence of blast disease was significantly $(P \leq 0.05)$ re-

Table 3: Efficacy of Seed Dressing Fungicides against Rice Blast Disease Incidence and Severity under Flooded and Hydromorphic Conditions.

Disease Incidence and Severity under different conditions IRRI SES Scale (0-9)

Treat -

Faro 29

Faro 11

ment

Hydromor- Flooded

phic
Hydromorphic

B1 BS B1 BS B1 BS B1 BS
A p r o n $9.0^{8}$
$7.7^{a}$
$5.7^{a}$
3. $0^{\mathrm{d}}$
$3.7^{\mathrm{d}}$
$1.7^{\mathrm{c}} \quad 2.3^{\mathrm{c}}$
$1.0^{\circ}$
plus

Fongoren $3.7^{d}$

$4.3^{\mathrm{c}}$

$4.3^{c}$

$3.0^{d}$

$1.7^{c}$

$1.0^{\mathrm{c}}$

$1.0^{c}$

I. $0^{\circ}$

Benomyl

$8.3^{\mathrm{a}}$

$5.7^{\mathrm{b}}$

$7.7^{3}$

$3.7^{\mathrm{d}}$

$2.3^{\mathrm{c}}$

$10^{\circ}$

3. $7^{\mathrm{d}}$

$1.0^{\circ}$

Control

$8.3^{\mathrm{a}}$

$6.3^{b}$

$7.0^{\mathrm{a}}$

$5.0^{h}$

$2.3^{\circ}$

$1.0^{\mathrm{c}}$

$2.3^{\mathrm{c}}$

$1.7^{\mathrm{c}}$

$\mathrm{BI}=$ Blasincidence $\mathrm{BS}=\mathrm{Blas}$ Serverity Figures followed with similar letter in each column are not significantly different at $(P \leq 0.05)$ using Duncan Multiple range test (DMRT). 
duced over the control in FARO 29 under both water regimes by fongorene. Disease ratings ranged from 8-9 for all the treatments compared to 3.6 recorded for fongorene tested plots. The interactions between the chemicals and the different water regimes were significantly only in FARO 29.

\section{Effect of seed treatment on disease severity}

(Table 3 ) showed that none of the treatments had any signifi- cant effect on blast severity in FARO 11 at both water levels. However, significant difference was recorded between the treatments under both water regimes in FARO 29. In FARO 29 plots, fongorene also had the least blast severity scores of 4.3 and Apron plus had the highest score of 7.7. Whereas 5.7 and 6.3 were recorded for the Benomyl and control respectively under the hydromorphic condition. In the flooded condition fongorene and Apron plus

\section{Table 4: Effect of Seed Dressing Fungicides Under Flooded}

and Hydromorphic Conditiofs on Tillering and Height of

Tiller Number and Height of Rice at Different Water Levels

Treatment

Faro 29

Fafo 11

Hỵdromorphic Flooded Hydromorphic Flooded

TN HR TN HR TN HR

(cm) $\quad(\mathbf{c m}) \quad(\mathbf{c m}) \quad(\mathbf{c m})$

Apron plus $\quad 26.0^{\mathrm{c}} \quad 68.3^{\mathrm{d}} \quad 12.8^{\mathrm{d}} \quad 67.7^{\mathrm{d}} \quad 12.7^{\mathrm{b}} \quad 111.3^{\mathrm{d}} \cdot 8.0^{\mathrm{a}} \quad 98.2^{\mathrm{e}}$

$\begin{array}{llllllll}\text { F o n g o } 24.3^{\mathrm{e}} & 7.0^{\mathrm{e}} & 17.3^{\mathrm{c}} & 66.3^{\mathrm{d}} & 15.3^{\mathrm{b}} & 106.7^{\mathrm{c}} & 11.7^{\mathrm{c}} & 104.0^{\mathrm{c}} \\ \text { rene } & & & & & \end{array}$

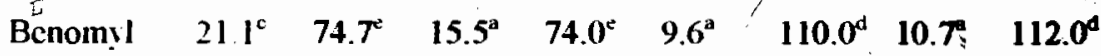

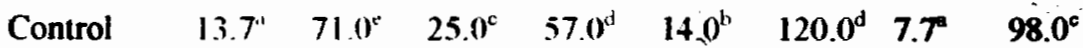

Bl=Blast incidence BS=Blast Serverity Figures followed with similar letter in

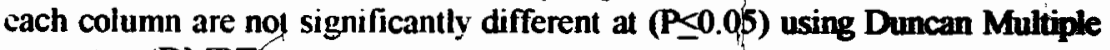
range test (DMRT). 
treatment had the least score of 3.0 followed by Benomyl 3.7 and the control had the highest disease rating of 5.0.

The effects of the fungicides in the control of blast disease indicated that fongorene significantly reduced blast incidence and severity in the two rice varieties both in the flooded and hydromorphic conditions. The disease score of 4.3 as compared to values of $5.7-7.7$ recorded for other fungicides makes fongorene superior over them in blast control using seed dressing method. While Benomyl and apron plus showed reduction of the disease only under flooded in FAROs 11 and 29 respectively. This findings are in agreement with earlier studies (Kannaiyan and Radhakrishnan, 1992; Ou, 1985; Reddy and Satyanaranyana, 1988; Singh and Rana, 1978), suggesting that fongorene has great potential as a seed dressing fungicides for blast control in Nigeria. Its simple method of application is an added advantage over foliar sprays because it is the most effective using seed treatment method. It eliminates the drudgery associated with applications of other forms of fungicides which are only effective

Table 5: Efiect of Seed Dressing Fungicides on the Yield of Rice Varieties FAROS 29 and FARO 11 Under Flooded and Hydromorphic Conditions.

Faro 29 Yield (t/ha)

T r e $\mathbf{t}$ - Hydromor- Flooded

ments

Apronplus $3.0^{\mathrm{a}}$

Controf

Fongorene $5.0^{b}$

Benomyl $\quad 3.1^{\mathrm{a}}$
Faro 11 Yield (t/ha)

Hydromor- Flooded phic

Figures with the same letter in each column are not significantly different using Duncan Multiple Range Test (DMRT) at $\mathbf{P} \leq 0.05$. 
through foliar spray.

\section{Effect of Seed Treatment on} Yield in Rice

Results of the effects of seed dressing with the fungicides under water regimes on rice tillering and height of rice (Table 4) showed no significant difference between the chemicals on the rice varieties under both water regimes

More tiller counts were significantly $(P \leq 0.05)$ obtained under hydromorphic than flooded environments for FARO 29, while no distinct trend was observed for FARO 11. There were no significant differences in height of rice between the flooded and hydromorphic conditions in each of the varieties tested (Table 4).
Table 5 shows that seed of FARO 29 treated with fongorene had a significantly $(\mathrm{P} \leq 0.05)$ higher yield $5.8 \mathrm{t} / \mathrm{ha}$ in the hydromorphic and insignificant higher yield of $4.4 \mathrm{t} / \mathrm{ha}$ in the flooded environments. The respective yields in untreated control plots were 3.1 and 3.5t/ha. Under hydromorphic condition, seeds of FARO 11 treated with fongorene had a significantly higher yield of 1.9t/ha while Benomyl treated seeds recorded significantly higher yield of $2.1 \mathrm{t} / \mathrm{ha}$ under flooded environment as against $1.1 \mathrm{t} / \mathrm{ha}$ and $1.3 \mathrm{t} / \mathrm{ha} \mathrm{ob}-$ tained respectively in their controls. There were significant interactions between the chemicals and the different water regimes on yield in both varieties.

The significant increase in yield in fongorene treated

\section{REFERENCES}

Awoderu, V.A. 1970. Identication of Races of Pyricularia oryzae in Nigeria. Plan: Disease Reporter 54:520-523.

Awoderu. V.A. 1974. Rise seases in Nigeria. PANS 20(4): $410-424$

Awoderu. V.A. 1990. E Vivion of Some Rice Varieties for Horizontal Resistance to Leaf Blast and Neck R o t (Pyricularia oryzea Cav.) in Cote d'Ivoire, Nigerian Journal of Plant Protection 13: 45-51.

Imolehin. E.D 1983. Rice Seed Borne Fungi and their Effects 
on Seed Germinations. Plant Disease. 67:1334-1336.

Imolehin, E.D. 1987. Occurrence of major Foliar Diseases of Rice in Nigeria. The Nigerian Agricultural Journal. 22:48-55.

IRRI, 1990. International Rice Research Institute Standard Evaluation System Scale (0-9) Los Banos, Philippines.

Kannaiyan, S. and Radhakrishanan, T. 1992. Effect of Seed Treatment with chemicals on the Control of Brown Leaf Spot and Blast Diseases of Rice in Seedling Stage (Helminthosporium Oryzae, Pyricularia oryzae, India.) Mathan Vov. 1982 V. 69(11) P.769-770.

Nagaraju, S. 1988. Chemical Control of Nursery Leaf Blast of Rice by Using Seed, Dressing Fungicides. Current Research, University of Agriculture Science Bangalore 1988, 17:4, 51-53.

Nakazawa, Y. 1985. Abstracts of the Annual Meeting of Pesticide Science Society of Japan (Tokyo), 35.

Ou, S.H. 1985. Rice Diseases $2^{\text {ad }}$ Ed. Commonwealth Agricultural Bureaux, Kew, Survey England.

Ou, S.H. 1994. Control of Rice Blast Disease L'sing Some fungicides. Annual Review of Phytopathology 8, 156-158.

Ou, S.H. 1995. Chemical Control of Rice Blast Disease. Annual Review of Phytopathology 7.383-410.

Reddy, AP.K. and Satyanarayana, K. 1988. Evaluation of New Organic Fungicides for the Control of Blast Disease of Rice. Pesticides, 22:9, 21-26.

Singh, R.A. and Bhatt, J.C. 1986. Effect of Seed Treatment with Systemic Fungicides on the Incidence of Foliar Blast on Rice. Indian Journal of Mycology and Plant Pathology 16: (3) 240-252.

Singh, R.A. and Rana, O.S. 1978. Field Evaluations of Some systemic and Nonsystemic Fungicides against blast Disease of Rice. Pesticides (India) 12 (6) 25-27. 